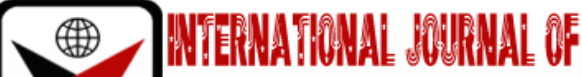

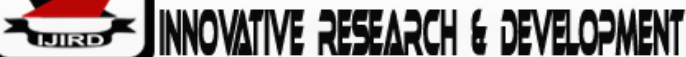

ISSN 2278-0211 (Online)

\section{Work-safety and Health Management on Employee Satisfaction: CSR Insider Approach: A Study of Lubcon Nigeria Limited}

\author{
Dr.Mairo Abdullahi \\ Senior lecturer, Department of Business Administration, \\ Usmanu Danfodiyo University Sokoto, Nigeria \\ Suleiman Ahmed Aremu \\ Lecturer, Department of Business Administration, \\ University of Ilorin, Nigeria
}

\begin{abstract}
In an attempt to sustain an evolving growth and compete favorably in a fast-growing market environment, management in various organization strategically invest enormously by adding values to their resources where labour is one. Doing this involves protecting the lives of employees from physical work injury and hazard in the work environment by not only making available the safety equipment as part of internal CSR employees related activities, but also train them on how to handle work safety equipment as well as their involvement in making safety policies. Despite these efforts by the management, employees still feel insecure and become unsatisfied with the job. Hence, the main objective of this research is to determine the effect of work safety and health management on employees' satisfaction with specific attention to LUBCON Nigeria limited. Descriptive survey design was adopted for the study as primary data were obtained through the use of questionnaire from 216 respondents. The result of the statistical analysis through the use of multiple regression revealed that work safety and health management have significant influence on employees' satisfaction $\left(R^{2}=.624\right.$, P-value $\left.\leq 0.05\right)$. It therefore concluded that work safety and health management have a significant impact on employees' satisfaction at LUBCON Nigeria Limited. The study therefore recommended that managementof LUBCON Nigeria Limited should intensify its efforts to strengthen the work safety and health conditions of her employees by laying hands on procuring new and up-to-date protective safety equipment so that it can create a drive-inemployee to put in their maximum best towards achieving organizational objectives. This is because, when employees feel motivated with an enabling operating environment, they feel secured and this creates inner drive which result in higher productivity.
\end{abstract}

Keywords: Workplace safety, Health condition, Internal CSR, Employees' job satisfaction

\section{Introduction}

Nowadays, businesses commit a lot of resources into finding, hiring and deploying the right employees into various available units in the organization. In fact, some estimates suggest that it costs roughly 16 percent of an annual salary to replace someone in a high-turnover, low-paying position and 20 percent in a mid-range position. Technically, that shows how important human capital is from a financial standpoint. However, it becomes a question that borders mind when seeing so many companies unintentionally ignoring employee health and safety condition when it comes to designing corporate social responsibility (CSR) initiatives. Whereas, most organizations spend too much time focusing on sustainable supply chains and efforts within the local community which are not equally bad, while totally forgetting that CSR is about serving all stakeholders including employees (Johansson, nd).

Similarly, a firm operating within the stakeholder or insider CSR approach tries to maximize the value of the stakeholders where employee is one. According to Vive (2006), the value of employees can only be maximized or appreciated by focusing on any of the proposed four employees related CSR activities. This includes pay and benefits, safety and health condition, work-life-balance as well as training and development.

Therefore, a work environment that is free from injuries and accidents attracts employees. They are more satisfied and productive in such an environment. Indeed, a safe working condition is not as important for both employers and employees alone, but the right of all employees to have safety in the workplace. It is necessary to stress that workplace safety is important regardless of the size of a company. Be it big or small, a company needs to incorporate safety in their workplaces, because a well implemented safety measures keep employees safe and also protect industry equipment. Therefore, it is not only the responsibility and duty of the employers, but the right of employees to be protected and kept safe by their employers. 
However, a company that directs its employees CSR related activities will manage their health and safe work conditions numerously. Among this is saying which emphasizes that the safer the work environment, the more productive it is. Here, productive employees are asset to all companies. For instance, productive employees can produce more output in less time, reducing operational costs for a company. Workplace safety equally promotes the wellness of employees and employers alike. Better safety equates better health. Healthier employees do tasks more efficiently and they are happier in general. (ILO, 2016)

Hence, accidents hardly occur in a safe working environment and this will help in less downtime for safety investigations and reduces costs for worker's compensation as well as reduces the time needed for employees to heal from injuries. Besides, damage to industrial equipment creates costs for replacement and repair. Hence, avoiding workplace injuries and damage to industrial equipment will incur fewer expenses and increase profit. Also, the concern of the employers about the safety of her employees, gives them confidence and comfort which in turns reduce absenteeism and ensure stability in their performance (ILO, 2016). It is against this background that this research study intends to study the effect of work safety and health management on employees' performance in LUBCON Nigeria Limited in Ilorin, branch.

\subsection{Statement of the Research Problem}

It is with sincerity to argue that it is not possible to measure the effects of human casualties after occurrence. The occurrence of which can either be fair or grievous to employees and their families who largely depend on them. In Nigeria today, it becomes difficult for employee in the organization of any type to boast of safety at his or her work place. Even though, some of these safety measures that are seen to be physically displayed in our various place of work are not only just there as window dressing for external body to see them, but they are equally not functioning as thought. Their nonfunctionality may be due to obsolete, expiration, physically damage and many more.

For where it is available and functional, most employees who are not even new do not have the skill on how to operate the safety gadgets successfully. Those that know how to operate it were due to chances when the items were being installed initially by the suppliers. Not only that, some employees due not really belief that no job exist without hazard, employers most at times are usually not used to creating strategies that will ensure and promote safety in their workplaces. More so, employers equally usually feel an unimportant to understand the desirable aspects of their employees' safety and protection terms. The understanding of which could be used to create enabling environment which could boosting productivity and improve quality of the products and services.

Similarly, it was also noted from the work of Jonathan and Mbogo (2016) that the majority of the staff were not made to be involved in the training programs that would equip them with safety skills in their workplace. Not only, that most of them were equally being prevented from being part of the team or committee who discusses safety policies in the workplace. This to a large extent jeopardized their safety at workplace and affected their preparedness on matters pertaining to health hazards and thus affect their general performance. More specifically in Nigeria, some of the existing policies and laws on occupational health and safety are obsolete and poorly enforced. Safety guideline compliance is equally very poor among both the employers and employee (Idowu\&lyabo, 2017). The gaps from the existing literature reviewed equally revealed that utmost attention has not been given to this topic. This is because, most of the studies available are not from Nigeria. It is against this background that this research studies investigates effect of work safety and health management on employees' satisfaction. Being a CSR insider approach with specific attention to LUBCON Nigeria Limited, Ilorin branch.

\section{Literature Review}

\subsection{Concept of Workplace Safety}

According to Idowu and Iyabo (2017), workplace safety is made up of one of the fundamental human needs, as showcase by Abraham Maslow in his theory of needs hierarchy. Kreitner(2007) posited that feeling of safety at work is rated as a very important factor in job satisfaction. Therefore, an attempt to satisfy this need, certain organizations incorporate it into their policy thrusts, guaranteeing workers' safe work execution under a controlled climatic physical, mental, and emotional conditions (Idowu\&Iyabo, 2017). Hence, policy of this nature is tagged health and safety. Stressing on work environment, Idowu and Iyabo conceptualized employee health as the absence of illness or disease emanating from the interaction of employee with work environment. While safety suggest to mean freedom from the occurrence of risk of injury or loss (Aswathappa, 2004). It could be inferred from the above definitions that author viewed employee safety as a way to protect workers from the danger of industrial accidents. More so, safety is equally perceived according to Lucas (2001), as the absence of injuries due to the interaction of the employee with work environment. Generally, safety could be summarized to means a condition of being safe from performing a work that is injurious in nature. While as a result, safety policies may encompass activities directed at either reducing or complete removal of hazardous conditions capable of causing bodily injuries (Idowu\&lyabo, 2017). Among the safety policies emphasized by ILO (2016) were (i) being aware and identifying workplace hazards (ii) implementing workplace safety programs (iii) providing proper safety training to employees (iv) using protective safety equipment (v) reporting unsafe working conditions (vi) practicing correct posture (vii) reducing workplace stress (viii) promoting regular breaks (ix) staying sober and alert (x) easy access to exits in case of emergencies and (xi) using mechanical aids.

\subsection{Internal Corporate Social Responsibility Practices}

The concept of internal corporate social responsibility is fast gaining attention as evidenced by modern researchers. Among them was Vives (2006) who conceptualized internal corporate responsibility as socially and 
environmentally responsible behavior. In his view, internal CSR practices for employees was observed to include; safety, health and well-being, training and participation, equal opportunities as well as work-family relationship. In the same vein, Brammer, et al., (2007) equally posited that internal CSR activities are linked or traceable to all the internal operations of the company. Inferring from the definitions above, it would be noticed that employees are considered very important internal stakeholder group and academic literature provides a range of CSR practices for meeting employees' expectations and needs.

Moreover, Longo et al.(2005) classified four employee-related CSR practices into four groups called 'value classes' which established value for the company's stakeholders, at the same time satisfy their various expectations. This value classes include the development of workers' skills, social equity, health and safety at work, well-being and satisfaction of the workers, and quality of work (Skudiene\&Auruskeviciene, 2012). Nevertheless, internal CSR is fundamental to the satisfaction of employees'psychological need of belongingness, because it fosters social relationships both within and outside the organization (Aguilera et al., 2007). Aguilera further argued thatsocially responsible organizations are usually perceived as fair organizations. In return from being fair, employees are more likely to trust their company, feel supported, perceive high quality of exchange of relationships with the company and management, feel proud and affiliated, and, thus, behave in a predictable.

\subsection{Employee Job Satisfaction}

The extent to which employees express their feelings about their jobs or job environment is tagged as 'employees' satisfaction. Employee satisfaction is suggested to mean the expectations of the employee about the workplace and his attitudes toward his job. Though, researchers have viewed it differently. Togiaet al., (2004) refer to it as a function of the degree to which one's needs are achieved in a job. To Weiss (2002), it is described as either apositive or negative evaluation of opinion on one's job or work situation. Therefore, job satisfaction can be suggested to mean employees' viewpoint of their work and organization. More so, there is a greater possibility that organizations with satisfied employees will record lower employee turnover rate while dissatisfied employees are likely to either leave their jobs for others or absent more often than employees who are satisfied (Kipropet al., 2015).

However, a number of studies have shown a positive relationship between job satisfaction and job performance (Judge et al.2001). Additionally, the existence of job satisfaction has a positive affiliation with the level of efficiency and quality of work. Holding unto this view, although job satisfaction is under the influence of many internal factors, it remains something internal that has to do with the way and how the employee feels which suggests that job satisfaction presents a set of factors that cause a feeling of satisfaction (Kipropet al., 2015).

Multiple theories related to definition of employee job satisfaction have been proposed in the literature. For instance, Herzberg's motivation-hygiene theoryfactors separated factors in creating job satisfaction from factors that led to job dissatisfaction. In his theory, factors that led to job satisfaction are called motivators and include achievement, recognition, work itself, responsibility and advancement. While factors that deny job satisfaction and lead to job dissatisfaction are called hygiene factors and they are administrative policies, supervision, salary, interpersonal relations and working conditions (Kipropet al., 2015).

\subsection{Workplace Health and Safety and Employee Job Satisfaction}

According to Kiprop, Kemboi, and Mutai (2015), safety culture of an organization is observed to be the combination of individual and group values, attitudes, perceptions, competencies and patterns of behavior that determine the commitment to, and the style and proficiency of an organization's health and safety management. The explanation for the proposed connection between job satisfaction and organizational safety relates to the fact that the degree of an employee's job satisfaction derives from meaningful organizational and social organizational values, norms, beliefs, practices and procedures operational at the workplace. In essence, the perceived level of support provided by an organization will turn out to be closely associated with safety and other organizational and social factors which are important for safety. If workers perceive that their organizations are supportive and are satisfied with the organizational structures in place, they are more likely to recognize that the organizations value their safety and general well-being as well.

This examination in response mirrors positively on their perceptions of the prevailing safety and influences organizational behavior. Thus, it is on record that when workers' basic needs are met consistently and the workers express job satisfaction, they display greater emotional attachment, involvement and express stronger feelings of allegiance and loyalty to their organizations (Kiprop, Kemboi,\&Mutai, 2015), In line with this, a number of studies have consistently found strong and positive relationships between job satisfaction and productive organizational behaviors such as perceived organizational support (Setton,1996), organizational citizenship behaviors (Manag, 2000) and fairness perception more than their dissatisfied counterparts, are motivated into safe work behaviors (Probst, 2001) and register relatively lower accident rates (Kiprop, Kemboi, \&Mutai (2015).

The basic underlining theory used in this paper is the Abraham Maslow's(1953) hierarchy of needs which emphasizes safety needs in its second stage of the hierarchy. According to him, safety, or security needs, relate to a person's need to feel safe and secure in their life and surroundings. Hence, motivation comes from the need for law, order, and protection from unpredictable and dangerous conditions. Therefore, in finding stability and security, a person must consider his/her physical safety which suggests seeking protection from the elements, violent conditions, or health threats and sickness(Adiele\& Abraham, 2013).

The trending internal CSR literature recommends that employees should demonstrates the need to acquire competences that will enable company to ensure the safe performance of work and the fulfillment of occupational health 
and safety requirements in conformity with the principles of corporate social responsibility. This is because, the business can only achieve its desired outcome only by espousal the rules of CSR under this approach (Gorny, 2017). Kiprop, Kemboi and Mutai (2015) suggested that health management policies should be developed to implement health practices in order to improve employees' health. Participation in the diversity training programs should be made compulsory for all employees and offer equal opportunities for employees in terms of promotion and education scholarships. Organization should equally provide allowances for employees on participation of social responsibility. It is the submission of Jonathan and Mbogo (2016) that the concerned authorities in conjunction with the various parties involved should organize training programs, involve them in discussion of safety policies so as to align them with the institutions strategic plans as far as Health and Safety at workplace is concerned.

- Ho: There is no significant effect of work safety and health management on employee job satisfaction.

\subsection{Empirical Review}

This section reviews the existing scholarly studies on how work safety as a subcomponent of component of stakeholder view of corporate social responsibilities (CSR) influence employees' satisfaction across sectors of economy within and outside Nigeria. Among these notable studies were the work of Koo and Ki (2020) who analyzed the effect of corporate social responsibility investment on employee safety. Obtaining secondary data in Korean listed company from 2012 to 2014. Regressing CSR scores by login in variables such as firm size, firm age, machinery ratio, cash operating flows, profitability, and sales growth rate as selected firm characteristics on the workplace injuries. The Ordinary Least Square (OLS) regression results show that higher corporate social responsibility scores are related with fewer working days lost owing to workplace injuries. The study's findings imply that investment in corporate social responsibility can improve workplace safety and contribute to a company's sustainable growth. However, it was noted that the years in which the data were collected were too small which could have effect on the outcome of result. More so, the author did not state the sector in where the firm whose information were used belong.

Similarly, Omer (2018) examined the impact of Corporate Social Responsibility (CSR) on employee job satisfaction. The author adopted exploratory research design to study employee's opinion toward CSR activities of Paky hospital in Iraq. The article captured CSR as the independent variable and employee's job satisfaction as dependent variable. The study randomly administered a structured questionnaire which consisted of eight items to 25 employees of Paky hospital. One-Sample Statistics t-test and ANOVA were run using SPSS.v.20 to test the validity of the hypotheses. The study concluded that there was an insignificant effect of CSR activities on job satisfaction of employees in Paky hospital; as well some of the elements or activities of CSR and job satisfaction are shared in the hospital.

Moreso, Rahian and AlKarim (2017) intensified effort to discover the impact of CSR on employee's job satisfaction in MNCs, Bangladesh. Four dimensions of Carroll's (1979) CSR consisting of economic, legal, ethical and philanthropic responsibilities were considered as the independent variables while employee job satisfaction was considered as the Dependent Variable. Stakeholder theory was adopted as a theoretical framework in order to provide guidance to the study. A structured questionnaire with 7 points Likert scale was used to collect the primary data through survey. 120 respondents from MNCs Chittagong city were conveniently selected as a sample size. The result of the data analysed through the SPSS showed that philanthropic, ethical and legal responsibility of CSR significantly and positively influenced employee job satisfaction where economic CSR was showing the negative relationship with employee job satisfaction. In general, employee job satisfaction is positively affiliated with organization's CSR practices in Bangladesh's MNCs. Nevertheless, the combination of the Carroll's (1979) CSR variables at this level would make the result to be so spurious which would surely have effect on the outcome.

In the same vein, Alkayed (2017) investigated the effect of Corporate Social Responsibility on employees' satisfaction with the aim to find out and identify strategies that affect the relationship between CSR activities and employees job satisfaction in Jordanian private hospitals. The author conceptualized CSR with promotion and working environment. The study randomly administered 100 copies of questionnaire to the employees across all private hospitals in Jordanian specifically those in Amman City. The results of Likert scales analyzed using descriptive statistics such as means and standard deviation shows that there was a significant effect of CSR on job satisfaction result from the two Hypotheses. The study recommended that private hospitals owners should make overall pay package available for employees to be based on efficiency and reward, also that equal opportunity should be made available to the employees so that they can put in their maximum best, at the same time, the Jordan private hospital management should strengthen the relationship that exist among employees in different management level. However, the study is critiqued of lumping the promotion and work environment together as there are components in which they can be split into which in no doubt improve the results.

Relatively, Jonathan and Mbogo (2016) conducted a study to seek to establish teachers' perspectives on their role in ensuring health and safety workplaces in secondary schools in Kenya. With a focus on all teachers and deputy principal working under Teachers Service Commission (TSC) and those working under the secondary schools' Board of Management (BOM). Out of the 50 participants forming the total population, 40 of them were teachers who were randomly selected while the remaining 10 were administrators and they were purposively selected across the ten schools. The study adopted descriptive research design. Data collected using questionnaire were presented and analyzed in descriptive form using simple percentage tables. The findings revealed that the majority of the teaching staff were not involved in the training programs that would equip them with safety skills in their respective workplace, while the study also noted that most of the respondents were not involved in discussing safety policies in their workplace, which to a large extent jeopardized their chances of safety at workplace. However, this study is critiques with the use of only descriptive analysis which might not really give the indebt analysis of the whole scenario. 
On a final noted, Kiprop, Kemboi and Mutai (2015) conducted a study to determine the effects of internal CSR practices on employee job satisfaction among the commercial Banks in Kenya. To do this, study regress CSR using; workplace health and safety conditions, work life balance, pay and benefits, as well as equality and diversity on employee job satisfaction. Having been guided by theories such as social exchange theory, theory of planned behavior as well as Stakeholder theory, adopted explanatory research design with target population of 283 employees from 17 Commercial Banks in Uasin-Gishu Kenya. The study used questionnaire to obtain primary information from the 165 employees gotten using stratified and random sampling technique. The findings from the study using SPSS to run both descriptive and inferential statistics such as Pearson correlation and multiple regression analysis that workplace health and safety, pay and benefit, equality and diversity, and work-life balance has a positive and significant effect on employee job satisfaction. However, the study is critiqued with being cumbersome as all the employees CSR related activities were taken together which would have affected the result.

\subsection{Gaps Identified}

From the related existing works reviewed, it was noticed that most of the works done on the subject matter were purely not from Nigeria. They were works based in countries such as Korea (Koo \& Ki, 2020), Iraq (Omer, 2018), Bangladesh (Rahian\&AlKarim,2017), Jordan(Alkayed,2017), and Kenya (Jonathan \&Mbogo, 2016; Kiprop, 2015). It was equally observed that some authors combined the all-CSR variables making the result too cumbersome such work includes; Kiprop, Kemboi\&Mutai, (2015); Rahian\&Alkarim, (2017). Some equally combined all the employees' CSR related activities against satisfaction. Author with such work includes, Alkayed (2017). Descriptive statistics were prioritized in the work of Jonathan \&Mbogo, 2016. At the same time, some of the researches were dominate in places like Educational Institution, Hospital, Manufacturing industries and banking industries. It is against this background that the current is undertaking to fill the above identified gaps by looking at the effect of workplace safety and health management on employees' satisfaction of LUBCON Nigeria Limited.

\section{Methodology}

This study adopted a survey research design. This is because the study used primary data to generate the necessary information needed through structured and self-administered questionnaire to the respondents. The questionnaire was divided into two sections. Section A covers Bio Data while section B addresses the basic questions on workplace safety and employees' satisfaction.

The scope of the study was limited to Oil Producing firms in Nigeria, narrowing it down to Kwara State being one of the states in the North Central with recent participation in the oil production and with special attention on LUBCON Nigeria Ltd. because of its closeness to the researcher. The targeted population of this study is the total no of staff of LUBCON Nigeria which is 470 (Company Human Resource Manager as 2020). Hence, the sample size was calculated using the Guilford and Flruchter (1973) formula for sample estimation, due to the fact that the whole population is too large to be studied. A random sampling technique was also employed to ensure that every member of the population has an equal chance in the selection process.

Guilford and Flruchter (1973) formula:

$$
\frac{N}{1+Q^{2} N}
$$

-Where:

$\mathrm{N}=$ Population $=470$

$\mathrm{Q}=$ Alpha $=0.05$

$$
\begin{aligned}
& \frac{N}{1+Q^{2} N} \\
= & \frac{470}{1+0.05^{2} 470}=216
\end{aligned}
$$

So, the sample size was 216 respondents, and in the course of administering the questionnaire. Questionnaire were structured to make scoring and collation simpler, using a 5 -point Likert scale with ' $5=$ Strongly agree' and ' $1=$ Strongly Disagree.'

To analyze the data collected from primary sources, multiple regression analysis was used to evaluate the impact of work safety management on employees' satisfaction using regression.

The model for hypothesis is stated below:

$Y=\alpha+\beta_{1} X_{1}+\beta_{2} X_{2}+\beta_{3} X_{3}+\beta_{4} X_{4}+\beta_{5} X_{5}+\varepsilon$

Where:

$\mathrm{Y}=$ Employees' satisfaction;

$\mathrm{B}=$ coefficients of variables;

$\mathrm{X}_{1}=$ Implementing workplace safety programs;

$\mathrm{X}_{2}=$ Providing proper safety training to employees;

$\mathrm{X}_{3}=$ Using protective safety equipment;

$\mathrm{X}_{4}=$ Promoting regular breaks;

$\mathrm{X}_{5}=$ Using mechanical aids

$\mathrm{E}=$ Error term. 


\subsection{Discussion of Results}

- $\mathrm{H}_{01}$ :Workplace safety and Health management does not have significant influences employees' satisfaction.

\begin{tabular}{|c|c|c|c|c|}
\hline Model & R & R Square & Adjusted R Square & Std. Error of the Estimate \\
\hline 1 & $.790^{\mathrm{a}}$ & .624 & .615 & .84526 \\
\hline
\end{tabular}

Table 1: Model Summary

a. Predictors: (Constant), Implementing Workplace Safety Programs, Providing Proper Safety

Training To Employees, Using Protective Safety Equipment, Promoting Regular Breaks

Source: Spss Printout, 2020

The table above presents the model summary of the effect of workplace safety and health management on employees' satisfaction. The table shows Correlation coefficient (R) and R-square to be 0.790 and 0.624 respectively. This explains that, workplace safety and health management's factors are highly and positively related to employees' satisfaction. Thus, its variables explained for about $62.4 \%$ of the variations in employees' satisfaction while the remaining $37.6 \%$ was explained by other factors not included in the model.

\begin{tabular}{|c|c|c|c|c|c|c|}
\hline \multirow{2}{*}{\multicolumn{2}{|c|}{ Model }} & \multicolumn{2}{|c|}{$\begin{array}{c}\text { Unstandardized } \\
\text { Coefficients }\end{array}$} & \multirow{2}{*}{$\begin{array}{c}\begin{array}{c}\text { Standardized } \\
\text { Coefficients }\end{array} \\
\text { Beta }\end{array}$} & \multirow[t]{2}{*}{$\mathrm{t}$} & \multirow[t]{2}{*}{ Sig. } \\
\hline & & $\mathbf{B}$ & Std. Error & & & \\
\hline \multirow[t]{6}{*}{1} & (Constant) & .283 & .157 & & 1.806 & .072 \\
\hline & Workplace safety implementation & .513 & .110 & .516 & 4.666 & .000 \\
\hline & Provision of training to employees & .323 & .086 & .295 & 3.774 & .000 \\
\hline & Use of Protective safety equipment & -.052 & .140 & -.051 & -.373 & .709 \\
\hline & Promoting regular break & -.551 & .158 & -.574 & -3.500 & .001 \\
\hline & Using mechanical aids & .546 & .195 & .521 & 2.797 & .006 \\
\hline
\end{tabular}

Table 2: Coefficients of Multiple Regression

a. Dependent Variable: Employees' Satisfaction

Source: SPSS Printout, 2020

The table 2 above shows the regression coefficient of workplace safety and health management on employees' satisfaction where workplace safety implementation, provision of training to employees, promoting regular breaks and using mechanical aids were statistically significant to employee's satisfaction with probability value of less than 0.05 . On the other hand, use of protective safety equipment was statistically not significant to employees' satisfaction as its probability value was greater than 0.05 . With this, it is sufficed to say that workplace safety and health management has significant effect on employees' loyalty. Therefore, the Null hypothesis is rejected while the Alternative hypothesis which states that work-safety and health management has significant effect on employees' satisfaction is hereby accepted.

\section{Finding and Conclusion}

Based on the analysis made, it was found that managing work-safety and employees' health condition is strongly and positively related to their satisfaction as evidenced by $R$ value of 0.790 . At the same time, $R^{2}$ value of 0.624 was equally found to suggest a $62.4 \%$ of employees' satisfaction by managing safety and health condition at workplace. Hence, the study concludes that a clear relationship and effect of managing work safety and health condition exists on employees' satisfaction.

\section{Recommendation}

Based on the conclusion drawn above, it is recommended that management of LUBCON Nigeria Limited should intensify its efforts to strengthen the work safety and health conditions of her employees by laying their hands on procuring new and up to date protective safety equipment so that it can create a drive-in employee to put in their maximum best towards achieving organizational objectives. This is because, when employees feel motivated with an enabling operating environment, they feel secured and this creates inner drive which results in higher productivity.

\section{References}

i. Adiele E.E. \& Abraham, N. M. (2013). Achievement of Abraham Maslow's Needs Hierarchy Theory among Teachers: Implications for Human Resource Management in The Secondary School System in Rivers State. Journal of Curriculum and Teaching, 2(1).

ii. URL: http://dx.doi.org/10.5430/jct.v2n1p140

iii. Aguilera, R.V., Rupp, D. E., Williams, C. A., \&Ganapathi, J. (2007), 'Putting the S back incorporate social responsibility, a multi-level theory of social change in organizations'. Academy of Management Review, 32(3), 836-863.

iv. Alkayed, W. (2017). The Effect of Corporate Social Responsibility on Job Satisfaction (Empirical Study on Jordanian Private Hospital). European Journal of Business and Management,9(12), 1-5. ISSN 2222-1905 (Paper) ISSN 2222-2839 (Online)www.iiste.org 
v. Aswathappa, K., (2004). Human resource and personnel management: Text and cases. (3rd ed.). New Delhi: Tata McGraw-Hill Publishing Company Limited.

vi. Brammer, S., Millington, A. \&Rayton, B. (2007), 'The contribution of corporate social responsibility to organizational commitment', International Journal of Human Resource Management, 18(10), 1701-1719.

vii. Gorny, A. (2017). Safety-at-work competences as a driver of corporate social responsibility. MATEC Web of Conference, 121. DOI: 10.1051/mateconf/201712111009

viii. Idowu, O. M., \&lyabo, O. V. (2017). Ensuring a Safe Working Environment in Nigeria: Reality or Myth.American Journal of Environmental and Resource Economics, 2(3), 107-115. doi: 10.11648/j.ajere.20170203.13

ix. ILO,(2016).Occupational Safety and Health Management System: An Applied and Training Guide for medium and large companies/ ILO DWT for North Africa and ILO Country Office for Egypt and Eritrea. ISBN: 978-92-2128404-8; 978-92-2-128409-3 (web pdf)

x. Johansson, A (nd).Employee Health and Safety Should Be CSR Priorities https://www.triplepundit.com/story/2017/employee-health-and-safety-should-be-csr-priorities/20336 retrieved from and accessed on 19/03/2021

xi. Jonathan, G. K. \&Mbogo, R. W. (2016). Maintaining Health and Safety at Workplace: Employee and Employer's Role in Ensuring a Safe Working Environment. Journal of Education and Practice, 7(29).

xii. Judge, T.A., Thoresen, C.J., Bone, J.E., and Patton, G.K. (2001), 'The Job Satisfaction-Job Performance Relationship: A Qualitative and Quantitative Review,' Psychological Bulletin, 127, 376-407.

xiii. Kiprop, C. P. \&Kemboi, A., \&Mutai, S. K. (2015). Effects of Internal Corporate Responsibility Practices on Employee Job Satisfaction: Evidence from Commercial Banks in Kenya. International Journal of Business and Management Review, 3(1), 24-40. www.eajournals.org

xiv. Koo, J. E., \& Ki, E. S. (2020). Corporate Social Responsibility and Employee Safety: Evidence from Korea. Sustainability, 12, (2649). 1-14. doi:10.3390/su12072649 www.mdpi.com/journal/sustainability

xv. Kreitner, R.., (2007). Management (10th ed.). Boston: Houghton Mifflin company,

xvi. Lucas, O., (2001). Health and safety policies. London: McGraw - Hill Inc,

xvii. Jonathan, G. K. \&Mbogo, R. W. (2016). Maintaining Health and Safety at Workplace: Employee and Employer's Role in Ensuring a Safe Working Environment. Journal of Education and Practice, 7(29).www.iiste.orgISSN 22221735 (Paper) ISSN 2222-288X (Online)

xviii. Longo, M., Mura, M. and Bonoli, A. (2005), 'Corporate social responsibility and corporate performance: the case of Italian SMEs'. The International Journal of Effective Board Performance, 5 (4), 28-42.

xix. Omer, S. K. (2018). The Impact of Corporate Social Responsibility on Employee's job Satisfaction. Journal of Process Management - new Technologies, International, 6(3). www.japmnt.com doi:10.5937/jouproman6-18296

xx. Probst T, Brubaker T. (2001) The effects of job insecurity on employee safety outcomes: cross-sectional and longitudinal explorations. Journal of Occupation Health Psychology, 6, 39 -159.

xxi. Raihan, T., \&AlKarim, R. (2017). CSR and Employee Job Satisfaction: A Case from MNCs Bangladesh. Global Journal of Human Resource Management, 5(3), 26-39. www.eajournals.org

xxii. Setton R. P., Bennett, N., \&Liden, R. C. (1996). Social exchange in organisations: perceived organizational support, leader-member exchange and employee reciprocity. Journal of Applied Psychology, 81, 219 - 27.

xxiii. Skudiene, V., \&Auruskeviciene, V. (2012). The contribution of corporate social responsibility to internal employee motivation. Baltic Journal of Management, 7(1), 49-67.

xxiv. Tongia A, Koustelios A, Tsigilis N (2004) Job satisfaction among Greek librarians. Library and Information Science Resource 26(3): 373-383

xxv. Vives, A. (2006). Social and Environmental Responsibility in Small and Medium Enterprises in Latin America. The Journal of Corporate Citizenship, 21, 39-50.

xxvi. Weiss, H.M. (2002), 'Deconstructing Job Satisfaction: Separating Evaluation, Beliefs and Affective Experiences. Human Resource Management Review, 12, 173-194. 